Volume 3 No. 2, Desember 2018

P ISSN 2442-594X | E ISSN 2579-5708

http://journal.iainlangsa.ac.id/index.php/tibyan

DOI: 10.32505/tibyan.v3i2.647

\title{
STABILITAS PEMERINTAHAN DALAM PERSPEKTIF ALQURAN
}

Government's Stability In The Qur'anic's Perspective

\author{
T. Mairizal \\ STAIN Teungku Dirundeng Meulaboh \\ 81mairizal@gmail.com
}

\begin{abstract}
:
Discourse on the concept of government is always being a lactual issue in Indonesia, especially in the lead up to regional elections or presidential elections. But essentially legislative elections cannot be ignored, each contestant in the general election competes to attract the votes of the people without regard to their spiritual competence. In this case, Alquran has formulated the basic concept of the government system. And this article tries to describe these basic concepts by using thematic and semantic approaches. By tracing various relevant terms, at least the Alquran uses awliyā', khalifah, and ulil amri terms. These terms show leadership includes the executive and legislature. To be a leader in a government, at least professional competence and physical abilities are needed. The stability of a government depends absolutely on the ability of the leader to carry out his obligations. Although religious status is still disputed, but as long as it is not related to the divine aspect, the people must obey the leader even though many things are not liked by him.
\end{abstract}

Keywords: Govermence, obligation, leadership, people

\begin{abstract}
Abstrak:
Diskursus tentang konsep pemerintahan selalu menjadi isu aktual di Indonesia, khususnya menjelang pemilihan daerah (Pilkada) atau pemilihan presiden (Pilpres). Namun, pada hakekatnya pemilihan legislatif tidak bisa di abaikan, setiap kontestan dalam pemilihan tersebut berlomba-lomba menarik suara rakyat tanpa memperhatikan kompetensi spiritualnya. Alquran telah merumuskan konsep dasar dari system pemerintahan. Artikel ini mencoba menjabarkan konsep dasar tersebut menggunakan pendekatan tematik dan semantik. Alquran menggunakan term awliyā', khalifah, dan ulil amri untuk menunjukkan kepemimpinan meliputi eksekutif dan legislatif. Untuk menjadi
\end{abstract}


pemimpin dalam suatu pemerintahan dibutuhkan kompetensi professional, serta kemampuan secara fisik. Kestabilitas suatu pemerintahan sangat tergantung pada kemampuan pemimpin dalam menunaikan kewajiban-kewajibannya. Meski status agama masih dapat diperselisihkan, namun selama tidak menyangkut aspek ketuhanan, maka rakyat harus mentaati pemimpin walaupun hal-hal yang tidak disukai.

Kata kunci: Pemerintahan, kewajiban, pemimpin, rakyat

\section{Pendahuluan}

Salah satu ajaran Islam adalah ajaran yang berkenaan dengan pengelolaan suatu komunitas atau lazim disebut dengan pemerintahan. Persoalan tersebut mulai diperselisihkan semenjak Rasulullah wafat, yang pada masa tersebut disebut persoalan imamah. Meskipun masalah tersebut berhasil diselesaikan dengan diangkatnya Abū Bakar (wafat. 23H/634 M) sebagai khalifah, namun dalam waktu tidak lebih dari tiga dekade masalah serupa muncul kembali dalam kehidupan umat Islam, yaitu

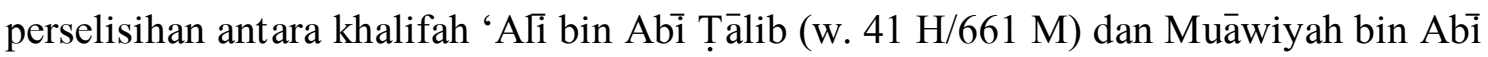
Sufyān (w. 64 H/680 M). Akhirnya berakhir dengan terbunuhnya khalifah 'Ali bin AbīṬālib dan bertahta Muāwiyah sebagai khalifah dan sekaligus pendiri kerajaan Bani Umayyah. ${ }^{1}$

Secara umum, bentuk pemerintahan menurut Alquran adalah suatu pemerintahan yang roda pemerintahannya beserta undang-undangnya berlandaskan hukum-hukum Allah dan Rasul-Nya serta meletakkan kepala negaranya di bawah pengawasan Allah. Sehingga dalam hal ini, semua kekuasaan legislatif, maupun yudikatif dari suatu negara harus ditempatkan dalam batas-batas perintah Allah dan Rasul-Nya.

Para Mufassir mengungkapkan ide-ide merekaterkait mengenai kekuasaan dalam perspektif Alquran. Ibnu Jarir al-Ṭabari (W. $310 \mathrm{H}$ ), yang menggunakan unsur kebahasaan dan riwayat dalam tafsirnya, menjelaskan bahwa raja adalah penyelenggara kesejahteraan penduduk negerinya dan pencegahjalan masuknya kezaliman. ${ }^{2} \mathrm{Al}-$ Zamakhsyari $(\mathrm{W} .538 \mathrm{H})$, yang menekankan aspek kesastraan, menegaskan bahwa Imam berfungsi sebagai panutan dan penyeru kebajikan. ${ }^{3}$ Muhammad bin Ahmad alQurțubi (W. $671 \mathrm{H}$ ), yang mengemukakan metode Fiqh dan analisis perbandingan, membahas tentang imamah mengikuti sistematika pembahasan Fiqh. ${ }^{4}$ Sedangkan menurut K.H. Munawwar Khalil yang dimaksud penguasa bukan hanya para hakim dan ulama melainkan juga ahlu al-Halli wa al-'Aqdi, yaitu orang yang berpengaruh

\footnotetext{
${ }^{1}$ Philip K. Hitti. History of The Arabs, (London: The Mcmillan Press Ltd., 1970), h. 139.

${ }^{2}$ AbūJa' farMuḥammad bin Jäir at-Ṭabarī, Jämi'ulBayān 'an Ta'wīl Ayi al-Qur'ān, (Cairo, Mustafa al-Bab al-Halabiwa Auladuh, 1373 H), jilid I h. 5 - 7, 32-34

${ }^{3}$ Mahmūd bin 'Umar al-Zamaksyarì, Al-Kasysyāf 'an Haqāiq at-Tanzīl wal 'Uyūn al-'Aqawil fíWujūh at-Ta'wīl, (Cairo, Mustafa al-Bab al-HalabiwaAuladuh, 1373 H), jilid I, h. 309, 382

${ }^{4} \mathrm{Abū}$ 'Abdillāh Muḥammad bin Aḥmad al-Qurțubī, Al-Jāmi' li Aḥkam al-Qur'ān, (Beirut, Daar Kitab al-'Araby, 2001), jilid I, h. $302-320$
} 
dibidang tertentu selain dibidang agama, dan istilah ini timbul semenjak masa khalifah 'Umar bin Khațāb.

Unsur utama dalam suatu pemerintahan paling tidak terdiri dari: pemimpin, rakyat yang dipimpin, dan wilayah pimpinan. Terdapat beberapa ayat dalam Alquran yang secara implisit dan eksplisit berbicara tentang tata kelola pemerintahan; diantaranya Q.S. an-Nisā' [4]: 58-59. Sebagian para ulama mengemukakan bahwa ayat ini berbicara tentang system pemerintahan dan dasar konklusi hukum Islam. Hal ini sebagaimana yang diungkapkan oleh al-Zamakhsyari ${ }^{6}$, al-Qurțubi, ${ }^{7}$ dan ulama-ulama tafsir lainnya. Ayat-ayat tentang kriteria pemimpin juga dapat menjelaskan sistem pemerintahan. Berkenaan dengan konsep kekuasaan di atas, maka perlu penggalian lebih dalam mengenai konsepsinya sesuai kandungan Alquran.

Artikel ini membahas mengenai konsep pemimpin yang ideal menurut Alquran. Ideal tersebut mencakup syarat-syarat, prinsip dan tanggungjawab pemimpin. Begitu juga halnya dengan berbagai batasan dan kewajiban rakyat yang dipimpin.

\section{Term-term yang Menunjukkan Pemimpin.}

Dalam Alquran ada beberapa istilah yang menunjukkan bahwa manusia sebagai penguasa atau pemimpin di muka bumi. Antara lain, awliyā', khalifah, dan ulil amri.

\section{Awliyā'}

Awliyā', yang berakar dari kata ولي pada dasarnya mengandung makna kedekatan, baik kedekatan fisikal maupun kedekatan maknawiah; berupa kedekatan dalam pertemanan, agama, pertolongan, dan keyakinan. Seseorang yang mengatur urusan orang lain disebut wali. Terkait dengan makna wali sebagai pemimpin, secara linguistik, menjadikan mereka sebagai wali memiliki dua makna: yaitu, memberikan dukungan dan pembelaan (jika lafalnya dibaca walāyah (dengan fathah), dan menyerahkan mandat atau memberi kekuasaan (jika lafalnya dibaca wilāyah (dengan kasrah). ${ }^{8}$

Semua makna derivatif dari kata wali diatas menunjuk kepada makna "kedekatan". Oleh karena itu, siapapun yang mempunyai kedekatan dengan pihak lain dapat disebut wali. Orang yang bersedia menolong orang lain, menjadi teman, sekutu, memberi warisan, adalah karena orang itu dekat dengan orang yang ditolongnya, baik sebagai teman, sekutu, ataupun sebagai anggota keluarga yang berhak mendapat warisan. Seorang ayah adalah wali bagi anak perempuannya karena antara keduanya terdapat kedekatan hubungan darah. Allah juga disebut sebagai wali kaum Mukmin (Q.S. al-Baqarah [2]:257) karena Dia dekat dengan mereka. Demikian pula seorang pemimpin disebut wali, karena dia mestinya dekat dengan rakyatnya, mendengarkan keluhannya dan dapat mengatasi segala kesulitannya. Maka secara politis dan

\footnotetext{
${ }^{5}$ Munawwar Khalil, UlilAmri, (Jakarta: Ramadhani, 1984), h. 34

${ }^{6}$ Maḥmūd bin 'Umar al-Zamaksyari, Al-Kasysyāf' 'an Haqāiq. h. 556.

${ }^{7}$ Abu் 'Abdillāh Muḥammad bin Aḥmad al-Qurțubì, Al-Jāmi’ li Aḥkam al-Qur’ān Jilid V h. 249

${ }^{8}$ Rāghìb Așfahānì, al-Mufradāt fịgharībilQur'àn, Saudi, MaktabahHizarMustofa al-Baz 1997, h.533
} 
geografis, muwālat al- kuffär tidak hanya berarti menjalin kerjasama atau beraliansi, tetapi juga menyerahkan wilāyah kita kepada orang kafir. Jadi, mengartikan kata wali - sebagai pemimpin tidak salah dan memiliki pijakan secara kebahasaan (etimologis). ${ }^{9}$ Dari beberapa makna yang disebutkan di atas serta menunjukkan bahwa kata wali atau awliyä' dapat diartikan sesuai dengan konteks ayat, bahkan Allah pun dapat dijadikan wali (Q.S. al-A'raf [7]: 196), begitu juga halnya dengan setan (Q.S. al-Baqarah [2]: 257).

\section{Khalifah.}

Kata khalifah berakar dari kata khalafa-yakhlufu. Akar kata tersebut dalam Alquran terulang sebanyak 127 kali dalm 12 kata jadian. Secara bahasa berarti mengganti, belakang dan berselisih. Bentuk kata kerja lainnya yang digunakan Alquran adalah istakhlafa-yastakhlifu yang berarti menjadikan khalifah. ${ }^{10}$ Dengan demikian kata tersebut dalam Alquran berarti mengganti, baik dalam konteks pergantian generasi-yang terkadang digambarkan dengan ungkapan yang hina (Q.S. Maryam [19]: 59)—atau berarti penggantian pemimpin (Q.S. al-A'raf [7]: 142).

Kata khalifah dalam bentuk tunggal hanya terulang dua kali dalam Alquran, yaitu ketika berbicara tentang pengangkatan nabi Adam sebagai khalifah (Q.S. alBaqarah [2]: 30) dan penobatan nabi Daūd sebagai pemimpin (Q.S. Șād [38]: 26). Pada ayat tersebut digunakan bentuk plural serta kata kerja masa lampau, kami telah, untuk mengisyaratkan adanya keterlibatan selain dari Tuhan, yaitu masyarakat dalam pengangkatan nabi Daūd sebagai khalifah. Pada prosesnya, beliau menjadi khalifah setelah membunuh Jalut (Q.S. al-Baqarah [2]: 251) sehingga memperoleh kekuasaan untuk mengelola suatu wilayah. Dengan demikian kata khalifah yang membicarakan pengangkatan Daūd adalah ke-khalifah -an dalam arti kekuasaan politik (pemimpin politik). Argument tersebut juga dikuatkan dengan kandungan ayat untuk menegakkan keadilan dalam ayat tersebut.

Bentuk plural dari kata khalifah ada dua macam, yaitu khalāif yang merupakan jamak dari khalifah, dan khulafá, yang pada hakikatnya kata plural dari khalif, tetapi kata khalif tersebut tidak digunakan dalam Alquran. ${ }^{11}$ Meski kedua kata plural tersebut memiliki makna yang sama, namun Alquran menggunakannya dalam konteks yang berbeda. Kata khulafá' digunakan dalam bentuk pembicaraan dengan umat nabi Hud (Q.S. al-A'rāf [7]: 69) dan umat nabi Șālih yang kafir kepada Tuhan (Q.S. al-A'rāf [7]: 74). Sedangkan kata khalāif digunakan dengan makna yang merujuk kepada umat manusia pada umumnya, dan orang-orang yang beriman khususnya, sebagaimana ketetapan Allah untuk umat nabi Nuh (Q.S. Yunūs [10]: 73), begitu juga dengan ketetapan Allah terhadap umat nabi Muhammad (Q.S. al-An‘ām [6]: 165).

${ }^{9}$ Dede Rodin, Kepemimpinan Non-Muslim Dalam Perspektif Alquran dalam Mutawatir: Jurnal Keilmuan Tafsir Hadits Vol. 7 No. 1, Juni 2017, h. 28

${ }^{10}$ Rāghīb Așfahāni, al-Mufradāt fỉgharibilQur'ān, h. 155

${ }^{11}$ Rāghīb Aṣfahāni, al-Mufradāt fìgharībilQur'ān, h. 155 


\section{Ulil Amri.}

Ungkapan ulil amri (أولي الأمر) merupakan frase nominal yang terdiri dari kata ulu (i), berarti pemilik, dan al-amr. Kata amr yang berinduk kepada kata a-m-r, dalam Alquran terulang sebanyak 257 kali. Sedangkan kata amr sendiri terulang sebanyak 176 kali dengan berbagai arti menurut konteks ayatnya. Kata amr bisa diterjemahkan dengan perintah (sebagai perintah Tuhan), urusan (manusia atau Tuhan), perkara, sesuatu, keputusan (oleh Tuhan atau manusia), kepastian (yang ditentukan oleh Tuhan), bahkan bisa juga diartikan sebagai tugas, kewajiban, dan kepemimpinan ${ }^{12}$. Dengan demikian frase tersebut dapat diterjemahkan pemilik urusan atau pemilik kekuasaan, atau hak memberi perintah. Kedua makna ini sejajar karena siapa yanga memberi perintah berarti ia juga mempunyai kekuasaan mengatur suatu urusan atau mengendalikan keadaan ${ }^{13}$.

Dalam Alquran kata ulil-Amri terulang 2 kali, yaitu dalam Q.S. an-Nisā' [4]: 59 dan 83. Sebagian ulama memahami kalimat tersebut bermakna para ahli Alquran dan fikih karena perintah berasal dari Alquran dan hukum kembali kepada ahli fikih. ${ }^{14}$ Makna lebih umum dikemukan oleh Ibn 'Āsyūr bahwa ulil amri tidak terbatas pada para sahabat atau para mujtahid, namun setiap orang yang diberi tanggungjawab oleh sekelompok orang untuk mengelola urusan mereka. ${ }^{15}$ Muhammad 'Abdūh mengemukakan empat pengertian dari ulil amri. 1) Para birokrat, 2) para hakim, 3) para intelektual, 4) imam-imam maksum (dari kalangan Syiah). Menurut Muhammad 'Abdūh sendiri, yang dimaksud dengan ulil amri adalah lembaga ahlul halli wal 'aqdi yang terdiri dari para birokrat, para hakim, para intelektual, serta tokoh-tokoh yang memiliki keahlian khusus yang relevan dengan kehidupan umat. ${ }^{16}$ Makna yang sama juga diungkapkan oleh Munawar Khalil. Apabila ahlul halli wal'aqdi, yaitu mereka yang berurusan dan memiliki otoritas di bidang keduniaan atau kemaslahatan umum selain yang bersangkutan dengan soal-soal keagamaan, maka yang dibutuhkan dari mereka adalah keahlian dan kewibawaan di bidang tersebut. Dengan demikian sangat memungkinkan ulil-amri tersebut bukan dari kalangan muslim sehingga iman tidak menjadi kriteria dari ulil-amri tersebut. Sungguhpun demikian berbagai kriteria lain yang berasal dari ajaran al-Alquran dapat pula diterapkan dalam menyeleksi ahlul halli Wal 'aqdi tersebut, seperti amanah, darma atau keadilan. ${ }^{17}$ Dengan mayoritas ulama menafsirkan ulil amri dengan ahlul halli wal 'aqdi, dapat dipahami bahwa ketetapan yang mereka putuskan merupakan hasil konsensus sebagaimana diberlakukan pada masa 'Umar bin Khaț̣̄ab.

\footnotetext{
${ }^{12}$ DawamDaharjo, EnsklopediAlquran, (Jakarta Paramadina, 2002), h. 466. Rāghīb Aṣfahāni, alMufradāt fí gharīibil Qur'ān, h. 24

${ }^{13}$ Abd Muin Salim, Konsepsi Kekuasaan Politik Dalam Alquran, (Jakarta, Raja Grafindo Persada, 1994), h. 231.

${ }^{14} \mathrm{Abū}$ 'Abdillāh Muhammad bin Aḥmad al-Qurțubi, Al-Jāmi’ li Ahkam al-Qur'ān, jilid V, h. 259

${ }^{15}$ Ṭăhir bin 'Āsyūr, at-Tahrīr wa at-Tanwïr, (Tunis, Daru Sahnun, 1997), jil. II, , h. 97

${ }^{16}$ Rasyīi Riḍā, Tafsir al-Manār, (Beirut, DarulKutubal-Í;lmiyah, tt), jilid V, h. 147

${ }^{17}$ Munawar Khalil, UlilAmri, (Jakarta : CV Ramadhani, 1984), h. 34.
} 


\section{Manusia Sebagai Representasi Tuhan}

Keberadaan manusia sebagai representasi Tuhan tidak lepas dari pernyataan bahwa manusia adalah khalifah, yakni sebagai wakil Tuhan di muka bumi. Kekhalifah-an tersebut merupakan mandat langsung dari Allah, yang diberi tugas dalam mengelola bumi-Nya. Sebagaimana dalam Q.S. al-Baqarah [2]: 30

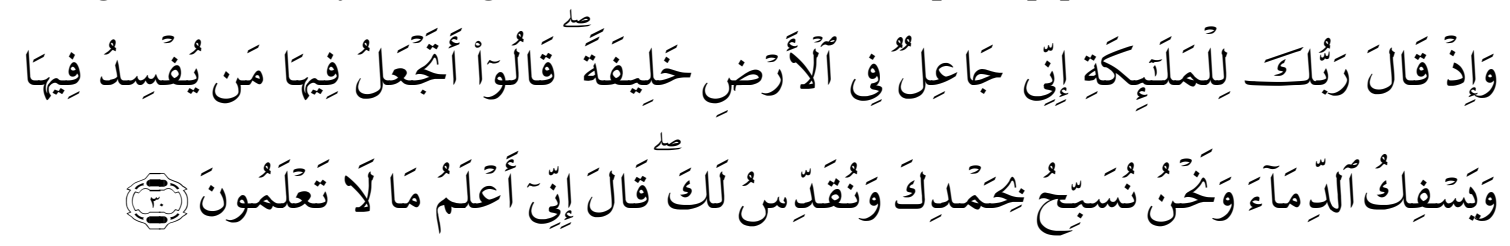

Artinya: "ingatlah ketika Tuhanmu berfirman kepada Para Malaikat: "Sesungguhnya aku hendak menjadikan seorang khalifah di muka bumi." mereka berkata: "Mengapa Engkau hendak menjadikan (khalifah) di bumi itu orang yang akan membuat kerusakan padanya dan menumpahkan darah, Padahal Kami Senantiasa bertasbih dengan memuji Engkau dan mensucikan Engkau?" Tuhan berfirman: "Sesungguhnya aku mengetahui apa yang tidak kamu ketahui."( Q.S. al-Baqarah [2]: 30)

Secara kiasan, khalifah dalam ayat tersebut dapat dimaknai dengan wakil yang mengemban tugas untuk menjalankan aktifitas sebagaimana dikehendaki, walaupun yang diwakili tidak harus (pernah) berada ditempat yang sama. Ayat tersebut menjadi dalil tentang keharusan adanya kepemimpinan yang mengatur tatanan hidup masyarakat. ${ }^{18}$ Ayat-ayat selanjutnya menjelaskan potensi yang dimiliki manusia sehingga dapat mengemban amanah tersebut. Potensi-potensi tersebut antara lain:

1. Potensi untuk mengetahui nama dan fungsi benda-benda alam.Dari sini dapat dipahami bahwa manusia adalah makhluk yang berkemampuan untuk menyusun konsep-konsep, menciptakan, mengembangkan, dan mengemukakan gagasan, serta melaksanakannya. Potensi ini merupakan bukti yang membungkam malaikat yang merasa wajar untuk dijadikan khalifah.

2. Pengalaman hidup di surga baik yang berkenaan dengan kecukupan dan kenikmatannya maupun rayuan iblis dan akibat buruknya.Pengalaman di surga adalah arah yang harus dituju dalam membangun dunia ini, kecukupan sandang, pangan, serta rasa aman terpenuhi, sekaligus arah terakhir bagi kehidupan akhirat. Sedangkan godaan Iblis dengan akibat yang fatal itu, merupakan pengalaman yang berharga dalam menghadapi rayuan iblis di dunia ini. Sehingga menjadi peringatan bahwa jangankan yang belum masuk, yang sudah masukpun bisa terusir apabila mengikuti rayuan syaithan.

3. Petunjuk-petunjuk keagamaan. Secara tegas,Alquran mengemukakan bahwa manusia diciptakan dari tanah dan Ruh Ilahi melalui proses yang tidak dirincikannya. Sedangkan reproduksi, walaupun dikemukakan tahapantahapannya, namun lebih banyak berkaitan dengan unsur tanah (material).

${ }^{18}$ Ṭāhir bin 'Āsyūr, at-Tahrïr wa at-Tanwïr, jilid I, hal 399, Abū 'Abdillāh Muhammad bin Ahmad alQurțubi, Al-Jāmi’ li Ahkam al-Qur'ān, jilid I, h. 305 
Sedangkangkan yang menyangkut immaterial antara lain ditemukan dalam uraian tentang sifat-sifat manusia dan uraian tentang fithrah, nafs, qalb, dan ruh. ${ }^{19}$

Alquran menegaskan bahwa kekuasaan mutlak adalah milik Allah, yang sering diungkapakan dengan kata mulk. Kata mulk mengandung arti penguasaan terhadap sesuatu disebabkan oleh kekuatan pengendalian dan keshahihannya. Artinya, mālik biasanya diterjemahkan dengan raja yang menguasai dan menangani perintah dan larangan. Karena itu kerajaan biasanya tercurah kepada manusia karena dapat menerima perintah dan larangan. Kata mālik dapat pula diartikan pemilik (Q.S. alFātiḥah [1]: 4) yang menunjukkan bahwa di hari itu kekuasaan Allah begitu menonjol sehingga tidak satu makhlukpun yang tidak merasakannya. ${ }^{20}$.

Namun Alquran menunjukkan bahwa sebagian dari kekuasaan tersebut Allah berikan kepada manusia yang Ia kehendaki. Sebagaimana dalam Q.S. 'ali 'Imrān [3]: 26

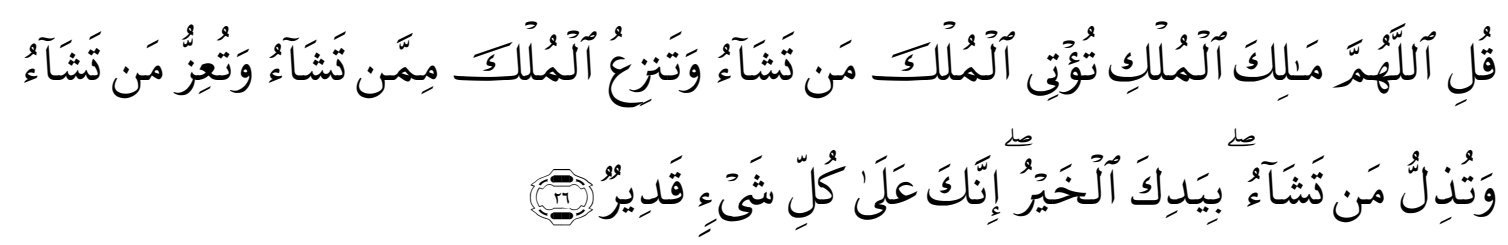

Artinya: "Katakanlah: "Wahai Tuhan yang mempunyai kerajaan, Engkau berikan kerajaan kepada orang yang Engkau kehendaki dan Engkau cabut kerajaan dari orang yang Engkau kehendaki. Engkau muliakan orang yang Engkau kehendaki dan Engkau hinakan orang yang Engkau kehendaki. di tangan Engkaulah segala kebajikan. Sesungguhnya Engkau Maha Kuasa atas segala sesuatu." (Q.S. 'ali 'Imrān [3]: 26)

Dengan makna Mulk lebih luas dari milk maka kekuasaan tersebut memiliki wewenang dalam mengatur segala aspek kehidupan masyarakat, walaupun tetap diikat oleh kekuasaan Allah. Kekuasaan tersebut diberikan dengan suatu perjanjian dengan Allah disatu pihak dan dengan masyarakatnya di pihak lain. Perjanjian dengan Allah dalam Alquran dengan 'Ahd, sebagimana doa nabi Ibrahim dalam surah Q.S. alBaqarah [2]: 124

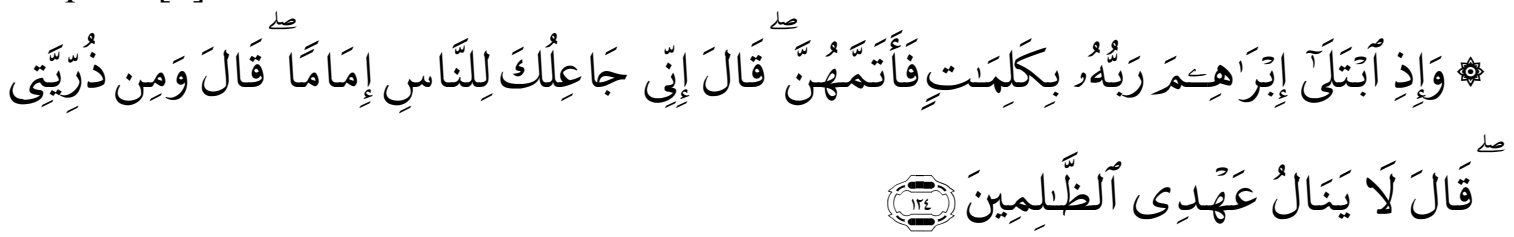

Artinya: "dan (ingatlah), ketika Ibrahim diuji Tuhannya dengan beberapa kalimat (perintah dan larangan), lalu Ibrahim menunaikannya. Allah berfirman: "Sesungguhnya aku akan menjadikanmu imam bagi seluruh manusia". Ibrahim berkata: "(Dan saya mohon juga) dari keturunanku". Allah

${ }^{19}$ Quraish Shihab, Wawasan Alquran, (Jakarta, Mizan, 1998), h. 282

${ }^{20}$ Quraish Shihab, MenyingkapTabir Ilahi, (Jakarta, Lentera Hati, 2003), h. 29 
berfirman: "Janji-Ku (ini) tidak mengenai orang yang zalim". (QS. alBaqarah [2]: 124)

Sedangkan perjanjian dengan masyarakatnya dinamai dengan Bai'at sebagaimana Alquran juga menjelaskan terntang nabi Muhammad yang datang para wanita kepada beliau untuk berbai'at (Q.S. al-Mumtahanah [60]: 12).

\section{Kriteria (Memilih) Pemimpin Menurut Alquran}

Para ulama memberi pamahaman yang berbeda-beda dalam menentukan pemimimpin ideal menurut sudut pandang atau pendekatan keilmuannya masingmasing. Syarat-syarat seseorang untuk menjadi pemimpin, kewajiban-kewajiban yang harus dijalankan adalah diantara ciri-ciri pemimpin yang ideal. Selain aspek religi, aspek kompetensi juga merupakan ciri lainnya. Meski penjelasan detailnya tertuang dalam pembahasan fikih, namun kisah-kisah dalam Alquran memberi pemahaman bagi masyarakat Islam. ${ }^{21}$

Q.S. al-Baqarah [2]: 247 menginformasikan:

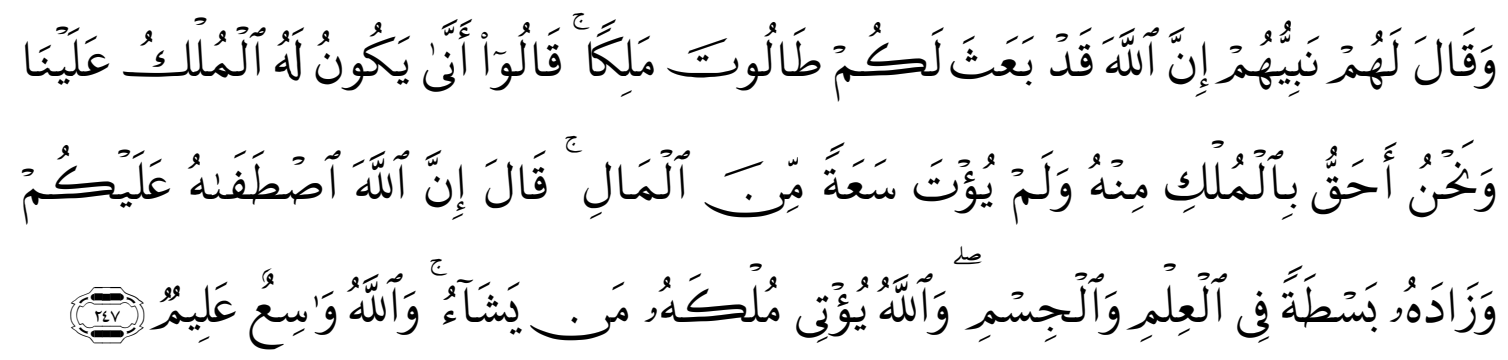

Artinya: "Nabi mereka mengatakan kepada mereka: "Sesungguhnya Allah telah mengangkat Thalut menjadi rajamu." mereka menjawab: "Bagaimana Thalut memerintah Kami, Padahal Kami lebih berhak mengendalikan pemerintahan daripadanya, sedang diapun tidak diberi kekayaan yang cukup banyak?" Nabi (mereka) berkata: "Sesungguhnya Allah telah memilih rajamu dan menganugerahinya ilmu yang Luas dan tubuh yang perkasa." Allah memberikan pemerintahan kepada siapa yang dikehendaki-Nya. dan Allah Maha Luas pemberian-Nya lagi Maha mengetahui."( Q.S. al-Baqarah [2]: 247)

Alquran tidak menjelaskan nama Nabi yang dimaksud, akan tetapi para ulama tafsir berpendapat bahwa beliau adalah Syamwil. Mengenai Țalūt sendiri, merupakan nama a'jamy seperti Jalūd dan Dawūd. Țalut merupakan nama lain dari kata Ṭuwāl yang berarti tinggi dan itu tergambar dalam ciri beliau yang berbadan besar. ${ }^{22}$ Ayat tersebut mengandung perngertian bahwa Allah mewahyukan kepada nabi Syamwil

\footnotetext{
${ }^{21}$ Dengan merujuk pada ayat pengangkatan Adam sebagai khlifah (al-Baqarah: 30), al-Qurthubi dengan pendekatan fikihnya misalkan, mengungkapkan sebelas syarat untuk menjadi pemimpin. LihatAbū 'Abdillāh Muhammad bin Aḥmad al-Qurțubi, Al-Jāmi' li Ahkam al-Qur'ān, jilid I h, 312, pendapat yang hampir sama juga dikemukakan oleh Taqiyuddin an-Nabhani, Taqiyuddin an-Nabhani, Sistem Pemerintahan Islam, al-Izzah, Jatim, 1997, h, 66

${ }^{22}$ az-Zamakhsyarì, Al-Kasysyāf' 'an Haqāiq......,jilid I, hal, 320, beliau juga berpendapat bahwa nama tersebut berasal dari Ibrani yang sesuai dengan nama Arab, beliau mangkaji dari segi ilmu saraf seperti kata hiththatun (gandum) dengan kata hinthatun.
} 
agar Țalut dijadikan raja bagi mereka. Alasan Allah menjadikan Țalut sebagai raja antara lain: 1) Kesiapan fithrah, 2) keluasan dalam ilmu yang menjadi bekal dalam peperangan, ataupun keluasan ilmu di bidang-bidang lain, 3) besarnya badan yang mencerminkan kesehatan, kekuatan, kebaranian dan kemampuan, 4) persetujuan dari Allah. Allah tidak memilih seorang pemimpin dengan kehendaknya tanpa ada sebab, tetapi semua apa yang Allah lakukan sesuai dengan hikmah tanpa ada pertentangan. ${ }^{23}$

Kemampuan seorang untuk melaksanakan tugasnya tergambar dari kecerdasannya dan badan yang besar (kekuasaan yang diperoleh). Kemampuan akal (ilmu) merupakan syarat utama dalam tatakelola suatu komunitas, apalagi di masa krisis, untuk mengetahui kebaikan. Sedangkan kekuasaan adalah jalannya untuk mencapai kebaikan tersebut. Kecerdasan -melalui pembicaraan yang bijak dan indahmengantar nabi Yūsuf untuk memperoleh kedudukan yang terpercaya dari raja ${ }^{24}$ (Q.S. Yüsuf [12]: 54), bahkan meliau meminta jabatan tertentu:

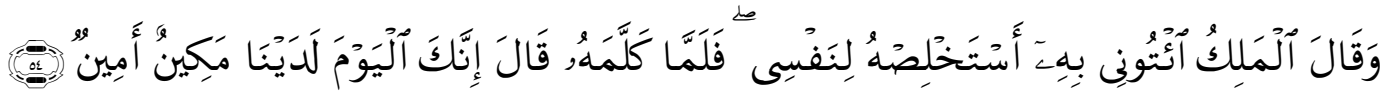

Artinya: "berkata Yusūf: "Jadikanlah aku bendaharawan negara (Mesir); Sesungguhnya aku adalah orang yang pandai menjaga, lagi berpengetahuan". (Q.S. Yūsuf [2]:

Pencalonan nabi Yusūf oleh diri sendiri dikarenakan pada masa tersebut -yang akan menghadapi tujuh tahun masa subur dan dilanjutkan tujuh tahun masa krisistidak ada satupun manusia lebih amanah dan mampu memenuhi kebutuhan orang banyak melebihi dirinya. Keadaan tersebut berlaku untuk zaman sekarang, ketika dianggap tidak ada satupun manusia yang mampu mengemban urusan suatu komunitas selain dirinya, dengan tetap berlandaskan pada alasan kepatutan sebagaimana alasan nabi Yūsuf. Keadaan demikian merupakan pengecualaian dari larangan meminta jabatan, sebagaimana dalam hadits nabi:

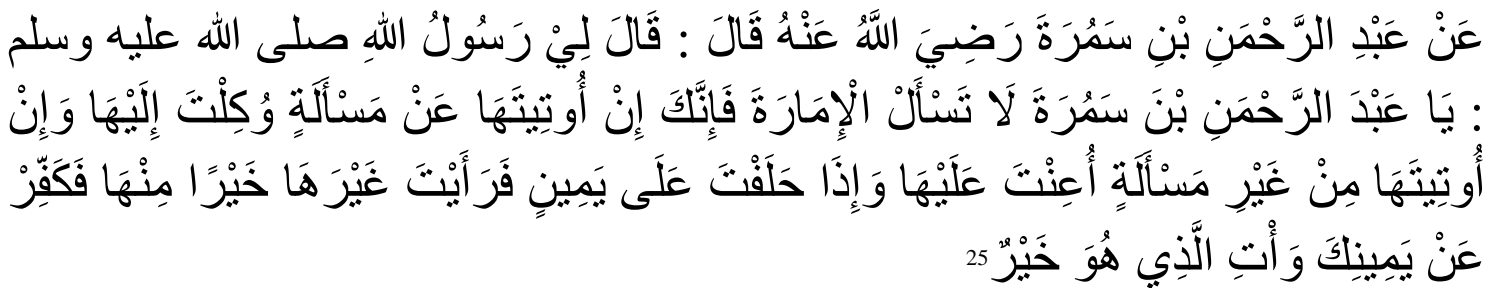

Artinya: "Dari Abdurrahman bin Samurah dia berkata: Rasûlullâh Shallallahu 'alaihi wa sallam telah bersabda kepadaku, "Wahai Abdurrahman bin Samurah, janganlah kamu meminta jabatan! Karena sesungguhnya jika diberikan jabatan itu kepadamu dengan sebab permintaan, pasti jabatan itu (sepenuhnya) akan

\footnotetext{
${ }^{23}$ Rasyīd Riḍ̄a, Tafsīr al-Manār, jilidII, h, 476, pendapat yang sama juga dikemukakan oleh azZamakhsyari, Al-Kassyaf 'an Haqaiqi......,jilid I, h, 320. Hal lain yang urgen dari histori ayat tersebut bahwa system hirarki bukan tata pemerintahan yang ideal dalam Islam. Tata pemerintahan dalam Islam dikenal dengan musyawarah, yang telah diawali semenjak kekhalifahan Abu Bakr.

${ }^{24}$ Para sejarawan berbeda pendapat tentang raja yang dimaksud antara Hyksos atau Amenhotep III dan IV, sehingga berbeda pula sosok raja yang menganut ajaran tauhid.

${ }^{25}$ Șahīh Muslim, Kitāb al-Aymān Babu Nadbi man ḥalafa Yaminan...
} 
diserahkan kepadamu (tanpa pertolongan dari Allâh). Dan jika jabatan itu diberikan kepadamu bukan dengan permintaan, pasti kamu akan ditolong (oleh Allâh Azza wa Jalla) dalam melaksanakan jabatan itu. Dan apabila kamu bersumpah dengan satu sumpah kemudian kamu melihat selainnya lebih baik darinya (dan kamu ingin membatalkan sumpahmu), maka bayarlah kaffârah (tebusan) dari sumpahmu itu dan kerjakanlah yang lebih baik (darinya)".

Keberadaan Ayat 55 di atas juga dijadikan argumentasi tentang kebolehan bekerja dibawah pimpinan non muslim Dalam konteks ini muncul diskusi di kalangan ulama berkaitan dengan keterlibatan non muslim dalam pemerintahan berdasarkan ayat-ayat Alquran, khususnya Q.S. al-Māidah [5]: 51, ataupun ayat-ayat lain yang secara tekstual melarang mengangkat orang-orang non muslim sebagai pemimpin.

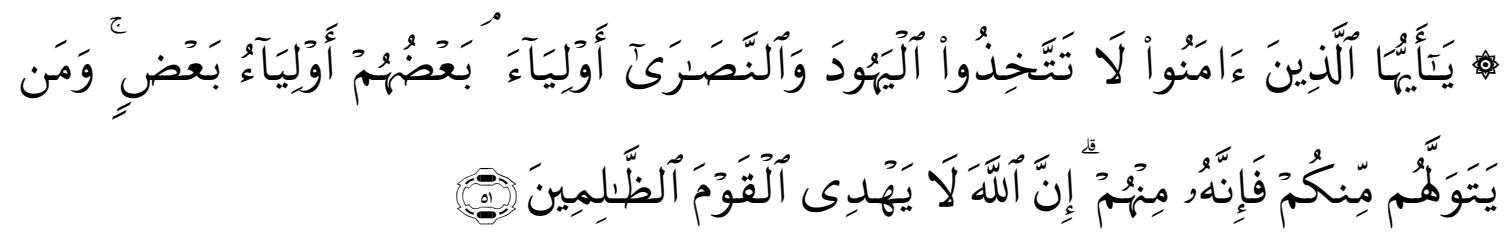

Artinya: "Hai orang-orang yang beriman, janganlah kamu mengambil orang-orang Yahudi dan Nasrani menjadi pemimpin-pemimpin(mu); sebahagian mereka adalah pemimpin bagi sebahagian yang lain. Barangsiapa diantara kamu mengambil mereka menjadi pemimpin, Maka Sesungguhnya orang itu Termasuk golongan mereka. Sesungguhnya Allah tidak memberi petunjuk kepada orang-orang yang zalim." (QS. al-Māidah [5]: 51).

Ayat-ayat tersebut dipahami oleh para ulama sebagai larangan menjadikan orang-orang kafir sebagai teman, penolong, atau seseorang yang mengemban tugas tertentu (pemimpin) berdasarkan konteks turunnya ayat. Al-Qurțubi secara muthlak memahami ayat tersebut secara tekstual, meski beliau juga berpendapat tentang kebolehan bekerja dibawah pimpinan non muslim, dengan ketentuan bahwa pemimpin non muslim tidak mengintervensi tugas yang diberikan pada bawahannya. ${ }^{26}$

Muḥammad Rasyìid Riḍā (w. 1935 M) memahami ayat-ayat yang melarang menjadikan orang-orang non muslim sebagai pemimpin secara kontekstual, beliau merujuk kepada kenyataan sejarah masa 'Umar bin Khațab dan pemerintahan Bani Umayyah dan 'Abbasiyah yang menjadikan orang-orang Yahudi Nasrani sebagai pekerja di kerajaannya. Beliau merujuk pada firman Allah dalam Q.S. Ali Imran [3]: 118:

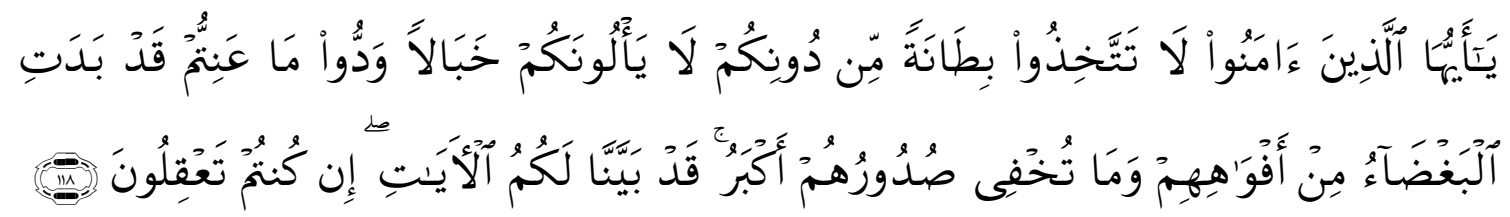

\footnotetext{
${ }^{26}$ Abū 'Abdillāh Muhammad bin Ahmad al-Qurṭubīi, Al-Jāmi' li Aḥkam al-Qur'ān, jilid IV, h. 174, bandingkan dengan jilid IX, h. 183
} 
Artinya: "Hai orang-orang yang beriman, janganlah kamu ambil menjadi teman kepercayaanmu orang-orang yang diluar kalanganmu (karena) mereka tidak henti-hentinya (menimbulkan) kemudharatan bagimu. Mereka menyukai apa yang menyusahkanmu. Telah nyata kebencian dari mulut mereka, dan apa yang disembunyikan oleh hati mereka lebih besar lagi. Sungguh telah Kami terangkan kepadamu ayat-ayat (Kami), jika kamu memahaminya."(Q.S. Ali Imran [3]: 118)

Dari ayat di atas Muḥammad Rasyīd Rị̣a memahami bahwa larangan tersebut merupakan larang bersyarat, yaitu orang-orang kafir yang selalu menimbulkan kesulitan bagi orang-orang beriman dengan berbagai cara, berusaha mencampakkan dalam bahaya, menampakkan kebencian dari ucapan mereka dan apa yang mereka sembunyikan dalam hati mereka lebih besar dari ucapan mereka. Di akhir ayatmenurut Rasyīd Riḍa-Allah telah menerangkan tanda-tanda yang membedakan antara yang sah dijadikan pemimpin atau penolong dan orang yang tidak sah karena kekhianatan mereka.

Selanjutnya Rasyìd Riḍa mengomentari bahwa larangan menjadikan pemimpin dari orang kafir bukanlah muthlak, tetapi hanyalah dengan syarat-syarat yang tersebut dalam ayat diatas, karena Allah mengetahui perubahan-perubahan yang terjadi pada bangsa-bangsa dan pemeluk agama tentang pro atau kontra, sebagaimana terlihat dari orang-orang Yahudi yang sangat membenci Islam pada awal-awal masa Islam kemudian berbalik membantu Islam dalam beberapa peperangan seperti penaklukan Andalusia. Dari sini nampak bahwa Alquran tidak menjadikan perbedaan agama sebagai penghalang untuk bekerja sama. Begitu juga Alquran tidak melarang kaum muslim untuk berbuat baik dengan siapa saja selama tidak berperang dalam agama (Q.S. al-Mumtaḥanah [60]: 8). ${ }^{27}$

Ulama kontemporer yang juga berafiliasi dengan gerakan Ikhwānul Muslimin Mesir, Sayyid Quțub (w. 1966 M), berpendapat bahwa keadaan yang diinformasikan ayat tersebut berlaku sampai zaman sekarang, sehingga umat Islam dilarang menjadikan non muslimim sebagai orang kepercayaannya. Beliau juga mengingatkan bahwa toleransi dalam Islam -selain larangan tersebut- melarang berbuat membenci dan dengki terhadap non muslim. Larang dalam ayat 118 tersebut menunjukkan bentuk antisipasi selama mereka tidak menghalangi dan memerangi (umat) Islam.Pada kondisi tersebut, umat Islam diperintahkan untuk melawan dengan tetap memperhatikan nilainilai kemanusiaan. ${ }^{28}$

Ulama Tunisia Ibnu 'Āsyūr (w. 1973 M) bahkan menguraikan delapan kategori beserta konsekwensinya dalam memahami kata awliyā'. Pertama. Seorang muslim menjadikan komunitas orang kafir sebagai kepercayaannya serta membenarkan kepercayaannya. Konsekwensinya adalah kafir, sebagimana sikap orang-orang munafik pada zaman Rasul. Kedua, kecenderungan pada, bahkan membantu, komunitas kafir

${ }^{27}$ Rasyìid Riḍā,Tafsīi al-Manār,jilid IV, h. 67

${ }^{28}$ Sayyid Quṭb, Fi Zilālal-Qur'ān. (Cairo: Dâral-Shurûq, 1412), jilid II, h. 389 
karena faktor kekerabatan tanpa meyakini agama mereka, namun pada saat bersamaan mereka memusuhi orang Islam - sebagaimana pada masa-masa awal Islam- maka konsekwensinya adalah dosa. Ketiga, bersikap abstain terhadap orang-orang yang memusuhi Islam, maka konsekwensinya adalah adalah terlarang karena dapat menjadi pembenaran terhadap perlakuan mereka. Keempat, menjadikan sekelompok orang kafir guna membahayakan sekelompok orang Islam lainnya, maka konsekwensinya sesuai dengan bahaya yang diakibatkan. Kelima, menjadikan sekelompok orang kafir guna membantu orang-orang Islam terhadap musuhnya, sikap demikian tidak dibolehkan oleh mayoritas ulama. Keenam, seorang muslim menjadikan seorang kafir sebagai teman dekatnya tanpa berakibat pada bahaya orang muslim, sikap demikian dibolehkan sebagaimana banyak ayat Alquran (Q.S. al-Mumtahanah [60]: 8). Ketujuh, bermuamalah dalam aspek duniawi. Kedelapan, kondisi bersimpati pada non muslim demi menghindari bahaya yang ditumbalkan, sebagaimana dibolehkan mengujapkan kafir dalam keadaan terpaksa (Q.S. an-Naḥl [16]:106). ${ }^{29}$

Penafsiran-penfsiran serupa juga dikemukakan oleh ulama Syiah, seperti Husain Ṭabațaba'i. Bahkan beliau mengingatkan bahwa larangan tersebut guna menghindari kesamaan adat dan dan akhlak. Karena pada hakikatnya, al-wilāyah adalah sarana untuk memperoleh kedekatan. ${ }^{30}$

Ayat-ayat Alquran beserta pendapat ulama menunjukkan bahwa apapun makna yang diungkapkan dari kata awliya $\vec{a}$, mengandung pesan bahwa larangan tersebut bersifat kondisonal, sekaligus dengan tujuan mengabaikan muslim lainnya. Sebagaimana firman Allah dalam Q.S. ' $A$ li 'Imrān [3]: 28

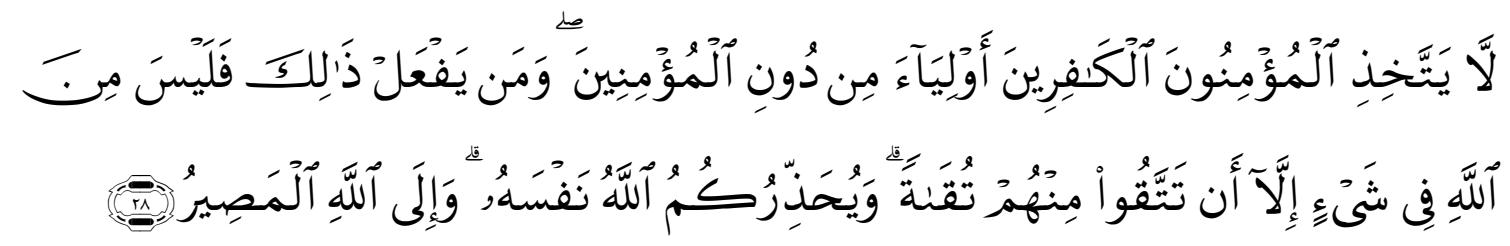

Artinya: "janganlah orang-orang mukmin mengambil orang-orang kafir menjadi wali dengan meninggalkan orang-orang mukmin. barang siapa berbuat demikian, niscaya lepaslah ia dari pertolongan Allah, kecuali karena (siasat) memelihara diri dari sesuatu yang ditakuti dari mereka. dan Allah memperingatkan kamu terhadap diri (siksa)-Nya. dan hanya kepada Allah kembali (mu). (Q.S.' $\bar{A} l i$ 'Imrān [3]: 28)

\footnotetext{
${ }^{29}$ Ṭāhir bin ‘'Āsyūr, at-Tahrïr wa at-Tanwir, jilid II, h. 218

${ }^{30}$ Muḥammad Ḥusain Ṭabạ aba'í, al-Mizān fĩTafsìr Alqurān, (Muassatu al-A'lami, 2006), 3jilid III, h. 114, dan jilid V, h. 283. Dede Rodin dan Kerwanto telah menguraikan secara khusus kedudukan non Muslim sebagai pemimpin. Masing-masing dengan judul: Dede Rodin, Kepemimpinan Non-Muslim Dalam Perspektif Alquran dalam Mutawatir: Jurnal Keilmuan Tafsir Hadits Vol. 7 No. 1, Juni 2017, h. 28. Kerwanto, Kepemimpinan non-muslim: Konsep wilāyah dalam al-Alquran Sebagai Basis Hukum Kepemimpinan non-muslim dalam Kontemplasi: Vol. 05 No. 02, Desember 2017
} 


\section{Menjaga Stabilitas Pemerintahan}

Perjanjian sang penguasa dengan masyarakat ataupun dengan yang Maha Kuasa merupakan amanat yang harus ditunaikan. Secara implicit, penafsiran-penafsiran ulama menjadikan QS. an-Nisā' [4]: 58-59 sebagai dasar peradaban manusia dalam pemerintahan. Bahkan Rasyīd Riḍ̄a, seorang pakar tafsir, mengatakan bahwa: Seandainya tidak ada ayat lain yang berbicara tentang pemerintahan, maka dua ayat ini telah memadai, ${ }^{31}$ Q.S. an-Nisā' [4]: 58-59.
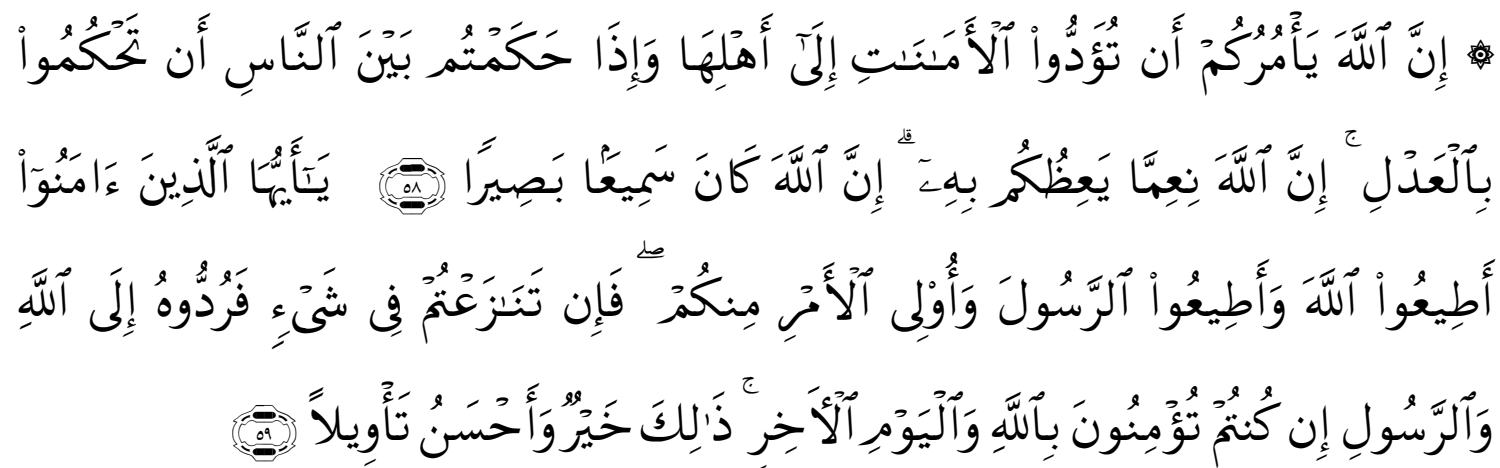

Artinya: "Sesungguhnya Allah menyuruh kamu menyampaikan amanat kepada yang berhak menerimanya, dan (menyuruh kamu) apabila menetapkan hukum di antara manusia supaya kamu menetapkan dengan adil. Sesungguhnya Allah memberi pengajaran yang sebaik-baiknya kepadamu. Sesungguhnya Allah adalah Maha mendengar lagi Maha melihat. Hai orang-orang yang beriman, taatilah Allah dan taatilah Rasul (Nya), dan ulil amri di antara kamu. kemudian jika kamu berlainan Pendapat tentang sesuatu, Maka kembalikanlah ia kepada Allah (Al Quran) dan Rasul (sunnahnya), jika kamu benar-benar beriman kepada Allah dan hari kemudian. yang demikian itu lebih utama (bagimu) dan lebih baik akibatnya. (Q.S. an-Nisā' [4]: 58-59)

Demi menjalankan roda pemerintahan yang stabil terdapat beberapa pokok persoalan yang terkandung dalam ayat diatas:

\section{Perintah Menunaikan Amanat}

Kata amanat adalah bentuk masdar dari kata amana-ya'manu, amn, amanah, dan aman, yang secara bahasa mempunyai arti tenang, tidak takut. Dalam ayat diatas kata tersebut tidak digunakan sebagai masdar tetapi sebagai obyek sehingga berarti sesuatu yang dipercayakan seseorang kepada orang lain dengan aman. ${ }^{32}$

Ada beberapa pendapat tentang pengertian kata amanat yang dirumuskan para ulama menurut pendekatan masing-masing. At-Ṭabari yang melihat ayat diatas ditujukan kepada para wali atau pemimpin pemerintahan mengemukakan bahwa yang dimaksud dengan amanah adalah hak-hak yang harus ditunaikan pemimpin kepada umatnya seperti pemebagian harta, mencegah kezaliman dan memberi keputusan yang

\footnotetext{
${ }^{31}$ Rasyīd Riḍā,Tafsīr al-Manār,tt, jilid V, h. 143

${ }^{32}$ Rāghīb Așfahāni, al-Mufradāt fī gharīibil Qur'ān, h. 32
} 
adil. ${ }^{33}$ Sebagai lawan dari khianat, al-Qurțbì melihat bahwa amanat harus ditunaikan kepada yang berhak dari semua golongan, baik kepada orang yang taat atau yang fasik, dan itu tercermin dalam ayat yang mengemukakan tentang pengkhianatan ahli kitab tentang sifat-sifat Rasul yang mereka ketahui. ${ }^{34}$

Muhammad'Abdūh berpendapat bahwa amanat adalah kewajiban seorang mukallaf yang berhubungan dengan orang lain untuk disampaikan kepadanya. Seperti harta dan ilmu. Baik melalui ikatan perkataan atau sekedar ikatan muamalah. Beliau lebih menekankan dengan istilah amanat al-'Ilmi. Seorang yang alim harus mewariskan ilmunya kepada orang lain. Selama terjadi kejahatan maka para ulama bertanggung jawab atas kejahatan tersebut, karena dia belum menunaikan amanatnya. Pendapat Muhammad'Abdūh diatas juga bertolak dari Q.S.' 'A li 'Imrān [3]: 187 di atas. ${ }^{35}$

Amanat dapat dipahami sebagai sesuatu yang abstrak ataupun konkrit. Sehingga memberikan tuntutan bahwa setiap individu, khususnya pemimpin, harus menunaikan amanahnya kepada yang berhak, baik ilmu berupa, keamanan -termasuk dalam menjalankan haknya masing-masing-, ekonomi yang layak dan pembangunan infrastruktur. Hak-hak tersebut merupakan fithrah manusia yang telah Allah tetapkan. Karena pada hakikatnya manusia memiliki amanah terhadap Allah, amanah terhadap sesama manusia, serta amanah terhadap dirinya (al-Anfal: 27-28)

\section{Perintah Menetapkan Hukum dengan Adil.}

Adil yang terambil dari bahasa Arab 'adl, mempunyai arti sama, persamaan yang merupakan adil itulah yang menjadikan pelakunya tidak berpihak. Keadilan diungkapkan oleh Al-Alquran dengan kata lain yang lebih umum, qisth, arti asalnya adalah bagian. ${ }^{36}$ Persamaan yang dimaksud adalah persamaan dalam hak. Alquran mengisahkan keadilan nabi Daūd yang datang kepadanya dua orang. Orang yang pertama mempunyai sembilan puluh sembilan ekor kambing betina dan orang yang kedua memiliki seekor kambing. Pemilik kambing pertama meminta agar kambing yang satu diberikan kepadanya agar genap seratus. Namun nabi Daūd tidak memutuskan perkara dengan membagi sama kambing-kambing itu, tetapi menyatakan bahwa pemilik sembilan puluh sembilan kambing itu telah berbuat aniaya dengan permintaannya itu (Q.S. Șād [38]: 22).

Substansi keadilan dalam konteks kepemimpinan adalah menetapkan hukum dengan adil dengan memelihara hak-hak dan martabat kemanusiaan. Dalam konsepsi Alquran yang dimaksud menetapkan hukum adalah melaksanakan hukum dan berada dibawah hukum Allah dan hukum-hukum Allah pula yang menjadi rujukan jika terjadi perselisihan. Ayat-ayat tersebut memberi peringatan bahwa menyimpang dalam menetapkan suatu keputusan merupakan penyimpangan dari fithrah manusia disatu pihak, dan menjadikan masyarakatnya sebgai korban hawa nafsunya atau kehendak

\footnotetext{
${ }^{33}$ Abū Ja'far Muhammad bin Jarīr at-Ṭabari, Jämi'ul Bayān 'an Ta'wīl Ayi al-Qur'ān,jilid V, h. 145

${ }^{34} \mathrm{Abu}$ 'Abdillāh Muḥammad bin Ahmad al-Qurțubī, Al-Jāmi' li Aḥkam al-Qur'ān, jilid V, h. 246

${ }^{35}$ Rasyīd Riḍā, Tafsìr al-Manār,tt, jilid V, h.143

${ }^{36}$ Ibn Manzụur, Lisān al- 'Arab, (Beirut, Daru Shadir, tt), jilid XXI, h. 430
} 
golongannya. Prinsip seperti ini juga ditegaskan sejak nabi Daūd diangkat menjadi khalifah (Q.S. Șād [38]: 28)

Pada beberapa ayat Alquran menyebutkan pluralitas masyarakat serta kaitannya dengan keadailan yang harus ditegakkan. Konsekwensi dari keadilan berlaku terhadap setiap ragam golongan (Q.S. al-Māidah [5]: 8), bahkan terhadap non muslim sekalipun sebagimana teguran kepada nabi SAW yang hampir saja menyalahkan seorang Yahudi karena terpengaruh oleh pembelaan keluarga seorang pencuri (Q.S. an-Nisā' [4]: 105). Generalisasi keadilan yang demikian sesuai dengan penyebutan kata baina an-nas (antara manusia) dalam Q.S. an-Nisā' [4]: 58.

Keadilan yang dibicarakan dan dituntut oleh Al-Alquran tidak hanya pada proses penetapan hukum atau terhadap pihak yang berselisih tetapi juga menuntut keadilan dalam aspek individual atau kemasyarakatan, bahkan keadilan terhadap diri sendiri baik ucapan atau tulisan (Q.S. al-An'ām [6]: 152). Keadilan-keadilan tersebut akan mengantarkan manusia pada ketaqwaan dan mendekatkannya pada kesajahteraan masyarakat secara umum (Q.S. al-A'rāf [7]: 96).

\section{Perintah Ketaatan.}

Ketaatan kepada Allah dan Rasul merupakan suatu yang mutlak yaitu mengamalkan ketentuan-ketentuan Alquran. Sama halnya dengan ketaatan pada Rasul yaitu mengikuti sunnahnya, bahkan pada aspek-aspek non-syar'ì. Sedangkan para penguasa merupakan pelaksana ajaran-ajaran yang universal tersebut. Berdampingan dengan amanat yang dibebankan kepada para penguasa serta menetapkan hukum dengan adil, Q.S. an-Nisā' [4]:58 yang diatas, ayat selanjutnya menekankan kewajiban masyarakat untuk taat kepada mereka.

Perintah taat yang digunakan dari kata 'ată'a yuți'u yaitu oleh Alquran berarti tunduk menerima secara tulus dan menemani. Ini berarti ketaatan terhadap perintah harus dengan kesadaran dan berpartisipasi. Dalam ayat yang dibahas diatas kata "taat" tidak digandengkan pada ulil amri untuk memberi isyarat bahwa ketaatan kepada mereka tidak berdiri sendiri tetapi berkaitan dengan ketaatan pada Allah dan Rasul. ${ }^{37}$

Meski sebagian ulama mensyaratkan dari kalangan muslim, namun mereka sepakat bahwa perintah yang harus ditaati adalah yang tidak meyalahi ketentuan Allah dan Rasul. ${ }^{38}$ Dengan definisi ulil amri, serta term-term lainnya, yang dikemukakan sebelumnya, maka wajib mentaati ulil amri ketika mereka menetapkan suatu hukum atau urusan yang berkenaan dengan kemaslahatan umat walaupun perintah tersebut tidak disetujui oleh yang diperintah.

\footnotetext{
${ }^{37}$ Ṭāhir bin ‘'Āsyūr, at-Tahrïr wa at-Tanwir, jilid II, hal 99

${ }^{38}$ Muhammad 'Abdūh dan Sayyid Quṭ mensyaratkan minna dalam hal ketaatan kepada ahlulhalli wal áqdi. Sementara ulama lain seperti ibn Asyuyr tidak mensyaratkannya. Al-Manar 148 Keharusan ulilamri dari kalangan muslim seakan bertentangan dengan penafsiran ayat-ayat lainnya dalam hal memilih pemimpin, sebagaimana dikemukakan sebelumnya.
} 


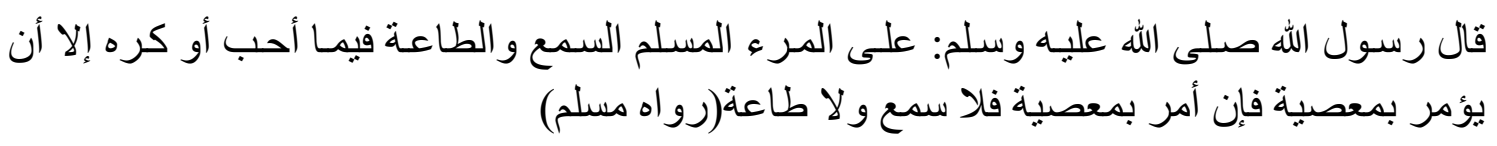

Artinya: "Seorang muslim wajib memperkenankan dan taat menyangkut apa saja (yang diperintahkan Ulul Amri) suka atau dibenci, kecuali apabila diperintahkan berbuat maksiat, maka ketika itu tidak boleh diperkenankan dan tidak juga ditaati “.(Riwayat Muslim)

\section{Perintah Kembali pada Allah dan Rasul.}

Ayat di atas menyeru orang-orang yang beriman agar bahwa setiap perselisihan yang terjadi dalam umat Islam harus dikembalikan pada Alquran dan sunnah. Yang demikian merupakan cara yang baik dalam menyelesaikan setiap perselisihan serta memberikan hasil yang baik pula. Penggunaan kata tanāza'a dalam memiliki arti perselisihan yang dahsyat. ${ }^{39}$ Perselisihan tersebut pada umumnya terjadi antara individu atau masyarkat dengan pemimpin.

Para mufassir berbeda pendapat tentang obyek yang harus dimusyawarahkan atau yang dikembalikan kepada Alquran dan sunnah. Al- Qurțubì yang menukilkan pendapat Mujāhid dan Qatādah, beliau mendukung bahwa obyek tersebut adalah urusan agama. ${ }^{40}$ Muhammad Rasyìd Ridā menyatakan bahwa obyek tersebut adalah urusan keduniaan, bukan urusan agama yang bersandarkan pada wahyu. ${ }^{41}$ Al-Marāghì berpendapat lebih luas, beliau mengatakan bahwa obyek yang diperselisihkan adalah segala sesuatu apa yang tidak dijelaskan dalam Alquran dan sunnah. Dengan demikian perselisihan tersebut mencakup urusan agama dan urusan dunia. Hal ini sesuai dengan kekuasaan ulil-amri yang harus ditaati. ${ }^{42}$

Dapat disimpulkan bahwa persoalan-persoalan yang telah ada petunjuk secara jelas dan tegas dari Tuhan atau melalui Nabi-Nya, tidak dapat diperselisihkan lagi. Pengembalian kepada Alquran dan sunnah (melalui musyawarah) hanya dapat dilakukan pada pesoalan-persoalan yang belum ada ketentuan secara tegas atau hal-hal yang mengalami perubahan dan pekebangan. Persoalan-persoalan yang diperselisihkan pada umumnya berbagai bentuk peradaban yang mengalami perubahan dan perkembangan yang ditetapkan secara global oleh Alquran. Argument demikian juga dikuatkan dengan tentang sesuatu dalam ayat tersebut. Suatu persoalan yang diterapkan pada suatu masa atau suatu masyarakat tertentu yang sesuai dengan budayanya, belum tentu dapat diterapkan pada masa atau masyarakat yang lain. Dengan demikian perintah mentaati ulil-amri meliputi hal-hal yang telah disepakati

\footnotetext{
${ }^{39}$ Ṭāhir bin 'Āsyūr, at-Tahrïr wa at-Tanwir, jilid II, h. 102

${ }^{40}$ Abdillah Muhammad bin Ahmad al-Qurthubiy, Al-Jāmi' li Aḥkam al-Qur'ān, V, h. 250, Hal ini karena beliau memahami kata ulil-amri yaitu para ahli Alquran dan ulama fikih dan beliau mengomentari barangsiapa yang tidak kembali kepada al-Alquran dan sunnah maka telah hilang iman darinya sesuai dengan lanjutan ayat tersebut.

${ }^{41}$ Rasyīi Riḍa,Tafsīr al-Manār, IV, h. 200

${ }^{42}$ Al-Maraghi, Tafsir al-Maraghi, V, (Beirut: Dar Fikri, tth), h. 72
} 
secara syar' $\bar{i}$, sedangkan hal-hal yang diperselisihkan dikembalikan pada Alquran, sunnah, ijmā' dan qiyās sesuai dengan konklusi hukum dari ayat tersebut.

\section{Penutup}

Kepemimpinan yang diemban oleh manusia merupakan kekuasaan yang mutlak milik Allah. Hanya saja kekuasaan-Nya dalam kehidupan duniawi dianugrahkan kepada manusia yang diungkapkan dengan term-term khalifah, ulil amri, dan awliyā'dalam menunjukkan pemimpin. Ketiga kata tersebut dapat dimaknai secara umum, dapat pula dimaknai secara khusu menyangkut kepemimpinan. Kelayakan manusia untuk diangkat sebagai pemimpin harus ditunjukan dengan kemampuan professional (ilmu), kemapanan fisik, dan kesiapan fitrah. Meski status agama masih dapat diperdebatkan, namun secara historis Alquran mengabadikan sosok raja Najasyi yang berbuat baik terhadap orang Islam. Dari beberapa ayat Alquran juga dapat dikonklusikan kebolehan bekerja dibawah kepemimpian non Muslim dalam hal duniawi.

Demi menjalankan pemerintahan yang berlandaskan Alquran, pemimpin hendaknya menyadari bahwa kekuasaannya merupakan amanah yang harus ditunaikan. Amanah tersebut dapat berupa sesuatu yang abstrak ataupun konkrit, sehingga memberikan tuntutan bahwa setiap individu, khususnya pemimpin, harus menunaikan amanahnya kepada yang berhak, baik ilmu berupa, keamanan-termasuk dalam menjalankan haknya masing-masing-ekonomi yang layak dan pembangunan infrastruktur. Hak-hak tersebut merupakan fitrah manusia yang telah Allah tetapkan. Karena pada hakikatnya manusia memiliki amanah terhadap Allah, amanah terhadap sesama manusia, serta amanah terhadap dirinya (Q.S. al-Anfâl [8]: 27-28). Pelaksanaan amanah biasanya akan menghadapi permasalahan-permasalahan yang berkaitan dengan hukum. Dalam keadaan demikian dibutuhkan keadilan dalam menetapkan hukum. Substansi keadilan dalam konteks kepemimpinan adalah menetapkan hukum dengan adil dengan memelihara hak-hak dan martabat kemanusiaan. Menyimpang dalam menetapkan suatu keputusan merupakan penyimpangan dari fithrah manusia disatu pihak, dan menjadikan masyarakatnya sebagai korban hawa nafsunya atau kehendak golongannya. Prinsip seperti ini juga ditegaskan sejak nabi Daūd diangkat menjadi khalifah (Q.S. Șād [38]: 28). Keadilan berlaku secara universal terhadap pluralitas masyarakat. Konsekwensi dari keadilan berlaku terhadap setiap ragam golongan (Q.S. al-Māidah [5]: 8).

Pemimpin merupakan pelaksana ajaran-ajaran Allah dan Rasul yang universal tersebut. Sehingga rakyat yang dipimpin harus mematuhi pemimpinnya selama tidak meyalahi ketentuan Allah dan Rasul. Dengan definisi ulil amri, serta term-term lainnya, maka wajib mentaati ulil amri ketika mereka menetapkan suatu hukum atau urusan yang berkenaan dengan kemaslahatan umat walaupun perintah tersebut tidak disetujui oleh yang diperintah. Adapun perkara-perkara yang diperselisihkan antara berbagai pihak hendaknya diselesaikan dengan musyawarah sesuai dengan Alquran dan 
sunnah, baik anatara pihak yang terkait atau perwakilan dari para ahli. Musyawarah tersebut dilakukan pada pesoalan-persoalan yang belum ada ketentuan secara tegas atau hal-hal yang mengalami perubahan dan pekebangan. Persoalan-persoalan yang diperselisihkan pada umumnya berbagai bentuk peradaban yang mengalami perubahan dan perkembangan yang ditetapkan secara global oleh Alquran.

\section{DAFTAR PUSTAKA}

Aṣfahānī, Rāghīb, Al-Mufradāt fĩ gharībil Qur'ān. Saudi: Maktabah Hizar Mustofa alBaz. 1997.

Daharjo, Dawam. Ensklopedi Alquran. Jakarta: Paramadina. 2002.

Hitti, Philip K. History of The Arabs. London: The Mcmillan Press Ltd. 1970.

Ibn al-Hajjāj, Muslim. Șahịh Muslim. Beirut: Daru al-Jail.Tt.

Ibn ‘'Asyūr, Ṭāhir.at-Tahrīr wa at-Tanwïr. Tunis: Daru Sahnun. 1997.

Ibn Manzūr. Lisān al- 'Arab. Beirut: Daru Shadir. Tt.

Khalil, Munawwar.Ulil Amri. Jakarta. 1984.

Marāghī, Muștafā. Tafsīr al-Marāghī.Beirut: Dar Fikri.Tth.

Nabhani, Taqiyuddin, Taqiyuddin an-Nabhani. Sistem Pemerintahan Islam. Jatim: alIzzah. 1997.

Qurțubī, Abū'Abdillāh Muḥammad bin Aḥmad. Al-Jāmi’ Li Aḥkām Alqurān. Beirut: Daar Kitab al-'Arabi. 2001.

Quṭb, Sayyid. Fī Zilālal-Qur’ān.Kairo: Dâr al-Shurûq. 1412.

Riḍā, Rasyīd. Tafsīi al-Manār. Beirut: Darul Kutub al-'Ilmiyah.Tt.

Salim, Abd Muin. Konsepsi Kekuasaan Politik Dalam Alquran. Jakarta: Raja Grafindo Persada. 1994.

Shihahb, M. Quraish.Menyingkap Tabir Ilahi. Jakarta: Lentera Hati. 2003. . Wawasan Alquran. Jakarta: Mizan. 1998.

Ṭabataba'ì, Muhammad Ḥusain. Al-Mizān fî̀ Tafsìr Alqurān. Muassatu al-A'lami. 2006.

Ṭabarì, Abū Ja'far Muhammad bin Jarìr.Jāmi'ul Bayān 'an Ta’wīl Ayi Alqurān. Cairo: Mustafa al-Bab al-Halabi wa Auladuh. $1373 \mathrm{H}$.

Zamakhsyarī, Mahmūū bin 'Umar.Al-Kasysyāf 'an Haqāiqi at-Tanzīl wa 'Uyūn al'Aqawìl fì Wujūh at-Ta'wìl. Cairo: Mustafa al-Bab al-Halabi wa Auladuh, $1373 \mathrm{H}$.

Kerwanto. Kepemimpinan non-muslim: Konsep wilāyah dalam Al-Alquran Sebagai Basis Hukum Kepemimpinan non-muslim dalam Kontemplasi: Vol. 05 No. 02, Desember 2017.

Rodin, Dede. Kepemimpinan Non-Muslim Dalam Perspektif Alquran dalam Mutawatir: Jurnal Keilmuan Tafsir Hadits Vol. 7 No. 1, Juni 2017. 